\title{
On a New Species of Medusa, Eucheilota hartlaubi n. sp.
}

\author{
By \\ F. S. Russell, \\ Naturalist at the Plymouth Laboratory.
}

With 6 Figures in the Text.

In November, 1933, a few medusæ were found in the plankton off Plymouth belonging to the genus Eucheilota. The only species of this genus so far recorded from northern European waters is Eucheilota maculata Hartlaub. The medusæ differed in several respects from this species, one constant difference being that the marginal vesicles never contained more than one concretion. In this respect they resembled E. duodecimalis A. Agassiz, but differed in having a much greater number of tentacles and marginal vesicles.

In October, 1934, the medusæ appeared again in considerable numbers and it was now possible to establish the constant features of the species which has apparently never been described before, except possibly for a drawing given by Hartlaub without a description (see below).

The youngest specimens obtained were just over one millimetre in height. These had four fully developed perradial tentacles, two bulbs having a spiral cirrus on either side, two with one cirrus and the rudiments of four interradial tentacle bulbs some with their cirri just appearing (Fig. 1). In one specimen there were four marginal vesicles, each with a single concretion, situated at the left-hand side of each rudimentary interradial bulb. In another specimen there were six marginal vesicles, an additional pair being present one on either side of the base of one of the perradial tentacle bulbs (Fig. 2). The first traces of the gonads were already appearing about half-way along the narrow radial canals.

At a later stage, $c a .2 .5 \mathrm{~mm}$. diameter, the four interradial tentacles were further developed and one specimen had eleven marginal vesicles, the four perradial bulbs each having one on either side. Figure 3 shows a slightly later stage, $3.5 \mathrm{~mm}$. in diameter.

Development proceeds fairly regularly until when full grown the medusa may have sixteen tentacles with occasionally two or three extra rudimentary ones (Fig. 4). Some of the adradial tentacles also are often not fully developed. The number of marginal vesicles may vary from 16 to 23 in number, and each has always only a single concretion. In many 
specimens there may be two lateral cirri on one or both sides of some of the tentacle bulbs. There are no marginal cirri.

The gonads are oval in outline and situated at the distal ends of the four radial canals and are separated from the margin of the umbrella by a distance of about half their length. Measurements made on a number of specimens gave the average dimensions of the gonads as $c a .0 \cdot 7 \mathrm{~mm}$. long

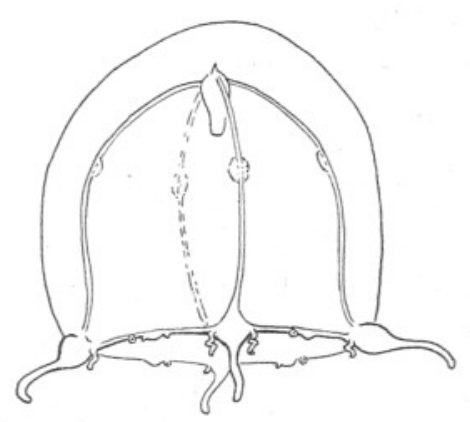

FIG. 1.-Eucheilota hartlaubi,n. sp. $1 \cdot 1 \mathrm{~mm}$. high. Plymouth, Sept. 29 th, 1934.

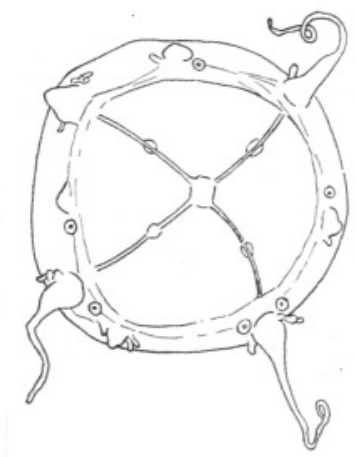

Fig. 2.-Eucheilota hartlaubi n. sp. $1.25 \mathrm{~mm}$. diameter. Drawn from above umbrella surface. Plymouth, Nov. 30th, 1933.

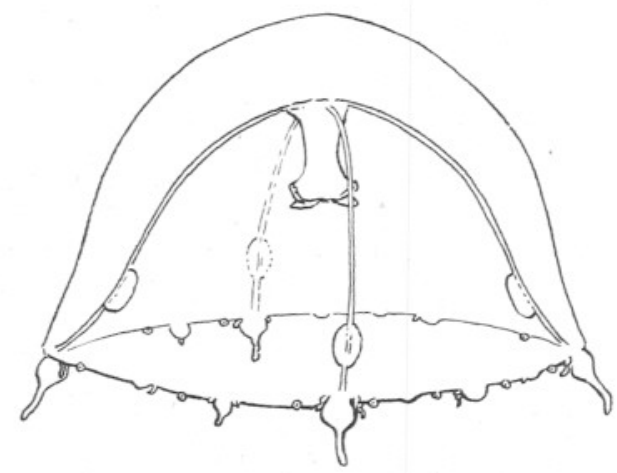

Fıg. 3.-Eucheilota hartlaubi n. sp. $\quad 3 \cdot 5 \mathrm{~mm}$. diameter. Velum and ring canal omitted. Plymouth, Oct. 30 th, 1934.

and $0.4 \mathrm{~mm}$. wide. The largest was $1 \mathrm{~mm}$. long. The gonads lie on the lateral surfaces of the radial canals and do not surround them ventrally, being distinctly longitudinally divided.

The mouth has four simple lips whose edges are thickly beset with nematocysts (Fig. 5).

The adult medusæ were generally $5-7 \mathrm{~mm}$. in diameter, though occasional specimens greater than $7 \mathrm{~mm}$. were met with. The colour of 
the tentacle bulbs by reflected light is rather distinctive, the main colouration being orange with a very vivid green central core, while the upper curve of the bulb is reddish (Fig. 6). In superficial appearance the medusæ resembled Phialidium hemisphericum, but the tentacle bulbs are decidedly larger than in that species, so much so that it is possible to separate preserved specimens of the two species with the naked eye. The tentacles also are shorter and do not coil spirally as they do in Phialidium.

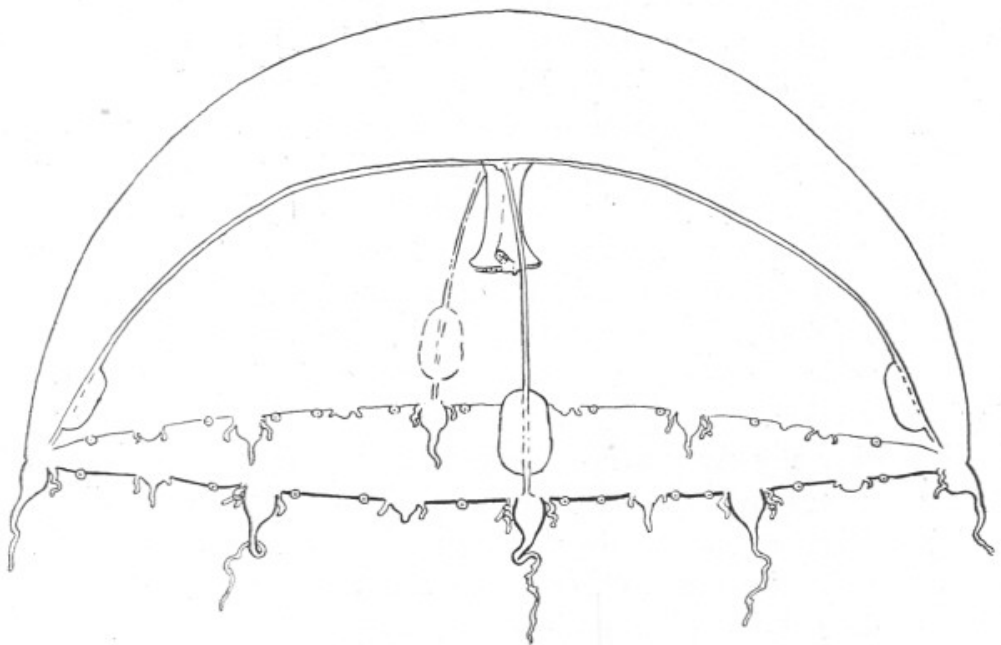

FIG. 4.-Eucheilota hartlaubi n. sp. $7 \mathrm{~mm}$. diameter. Drawn slightly diagrammatically; velum and ring-canal omitted.

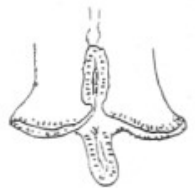

FIG. 5.-Mouth of Eucheilota hartlaubi n. sp.

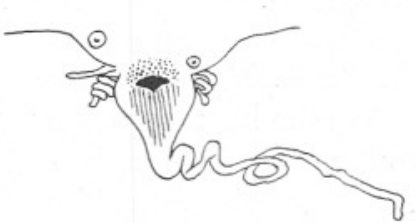

FIG. 6.-Perradial tentacle bulb of Eucheilota hartlaubi n. sp. $2 \frac{1}{2} \mathrm{~mm}$. diameter. Dots reddish; black, green ; and line shading orange.

In its earliest stages of development this medusa somewhat resembles the medusa described by Hartlaub (1897, p. 498 ; Taf. XXI, Figs. 15-17 and Taf. XXII, Fig. 11) as produced by the hydroid Campanulina hincksii Hartlaub.* He was only able to keep these medusæ for a short time. When first budded off they had four perradial tentacles each with one cirrus at its side; there were also four interradial marginal cirri, and between each cirrus and tentacle was a marginal vesicle with a single

* I am indebted to Dr. P. L. Kramp for pointing out this similarity. 
concretion. On further development the interradial cirri were thrown off and the rudiments of tentacles appeared in their places, while at the base of each perradial tentacle bulb there was now a cirrus on either side. It is at this stage that they resemble the medusæ here described. Hartlaub associated this young medusa with Eucheilota maculata Hartlaub, giving $C$. hincksii as its hydroid. Kramp, however (1926, p. 244) has shown that this conclusion was wrong since the youngest stages of E. maculata are not the same as the little medusæ described by Hartlaub.

On the last page of his work on the Craspedote Medusæ in the Nordisches Plankton (1917, p. 418), Hartlaub figures an adult medusa that resembles very closely the medusa that I am now describing. Hartlaub describes this medusa as "Medusa n.g. n.sp." reared from the hydroid Lovenella clausa Lovén, with the remark that the fully developed tentacles are mostly 16, but can increase to 24 . Except for the figure and its legend Hartlaub gives no description of the medusa or how he reared it. The drawing shows each tentacle to be flanked by two lateral cirri, and on the nearer umbrella margin are shown six marginal vesicles each with a single concretion.

On receiving my manuscript for perusal Mr. E. T. Browne kindly sent me drawings and notes that he had made many years ago obviously referring to the present species at Plymouth, and mention of which he had made under the name of Mitrocomium sp. (?) (1898, p. 190).

Some of the details of his specimens were as follows :-

Sept. 23rd, 1893. $3 \mathrm{~mm}$. diameter. 4 perradial tentacles; 4 interradial developing tentacles ; 3 rudimentary adradial bulbs. Each of the per- and interradial bulbs had a cirrus on either side. 16 marginal vesicles, with single concretions.

Sept. 25th, 1893. $1 \frac{1}{2} \mathrm{~mm}$. diameter. 4 perradial tentacles ; 4 interradial bulbs developing; each bulb with a cirrus on either side; 3 very rudimentary adradial bulbs. 10 marginal vesicles, with single concretions.

Aug. 24th, 1895. $1 \frac{1}{2} \mathrm{~mm}$. diameter. 4 perradial tentacles ; 4 interradial bulbs; all bulbs with a cirrus on either side. 9 marginal vesicles, with single concretions.

Sept. 8th, 1897. $5 \mathrm{~mm}$. diameter. 4 per- and 4 interradial tentacles ; 8 adradial bulbs; pair of cirri at base of each bulb.

Sept. 8th, 1897. $2 \mathrm{~mm}$. diameter. 4 perradial tentacles; 4 interradial bulbs and 8 adradial bulbs. One cirrus on each bulb, 8 marginal vesicles with single concretions.

Other specimens were taken from Salcombe, in July and August, 1900, from tow-nettings sent by Mr. R. A. Todd; and in September, 1897, $\frac{1}{2}$-mile off Mewstone and 2 miles S.W. of the Eddystone.

Attached to Mr. Browne's notes was the following very interesting 
extract from a letter written by Hartlaub from Helgoland on January 15th, 1913.

"Last summer I had the good fortune to rear the medusa Lovenella clausa from the Hydroid to the fully grown sexually adult stage and to make sure that it is a new Eucopid which is quite common in our Plankton, but because of its likeness with Phialidium has remained unnoticed till now. I send you some specimens."

Mr. Browne in his manuscript notes states that the medusæ received from Hartlaub are identical with his Mitrocomium sp.

Although the hydroid Lovenella clausa is not given in the Plymo th Marine Fauna, it is recorded by Allen from the Prawle stony ground (1899, p. 449). Hincks in his "History of British Hydroid Zoophytes" also records the species from Torbay.

We would seem therefore to have conclusive evidence that the medusa described in this paper is indeed that figured by Hartlaub as coming from Lovenella clausa and I propose to call it Eucheilota hartlaubi n.sp. in memory of one who devoted the greater part of his life to the study of hydroids and medusæ and whose critical revisions placed our knowledge on a much surer foundation.

The following is the description of this new species.

\section{EUCHEILOTA HARTLAUBI N.SP.}

Flattened hemispherical medusa, apical jelly moderately thick. Four narrow radial canals. Stomach small, no peduncle; manubrium with four simple lips thickly beset with nematocysts. Sixteen, occasionally more, tentacles with large conical bulbs, flanked on either side by one or two lateral spiral cirri. No marginal cirri. 16 to 23 marginal vesicles, closed, each with a single concretion, and situated roughly one between each tentacle. Velum narrow. Gonads oval, longitudinally divided, situated on distal ends of radial canals, ca. $0.7 \mathrm{~mm}$. long by $0.4 \mathrm{~mm}$. wide.

Colour : by reflected light, tentacle bulbs orange with a core of bright green and a reddish summit, manubrium pale greenish yellow, gonads with greenish tinge.

Size, ca. 5-7 mm. in diameter, occasionally up to $9 \mathrm{~mm}$.

Time of year: present in plankton from July to January, mainly October and November.

Hydroid : Lovenella clausa Lovén.

Eucheilota hartlaubi does not usually occur in great numbers at Plymouth although it is quite common. Once, however, on October 11th, 1934, several hundred specimens were taken in a 30 -minute oblique haul with the stramin ring-trawl. 


\section{ADDENDUM.}

Since going to press I have seen the description by Neppi and Stiasny of Eucheilota maasi (Arbeit. Zool. Inst. Univ. Wien u. Zool. Stat. Triest. Bd. XX, p. 46; Pl. III, Figs. 32 and 33). These authors had not a full series of developmental stages and suggested a possible connexion between this species and Eirene plana Neppi. From the description and figures given by them there is a possibility that $E$. hartlaubi n. sp. and E. maasi Neppi and Stiasny may prove to be the same species.

\section{REFERENCES.}

Allen, E. J. 1899. On the Fauna and Bottom-Deposits near the Thirty-Fathom Line from the Eddystone Grounds to Start Point. Journ. Mar. Biol. Assoc., N.S., Vol. V, No. 4, pp. 365-542.

Browne, Edward T. 1898. On the Pelagic Fauna of Plymouth for September, 1897. Journ. Mar. Biol. Assoc., N.S., Vol. V, No. 2, pp. 186-192.

Hartlaub, Clemens. 1897. Die Hydromedusen Helgolands. Wiss. Meeresunters. Abt. Helgoland, N.F., Bd. II, pp. 449-536; Taf. XIVXXIII.

Hartlaub, Clemens. 1917. Nordisches Plankton, Lief. XIX, XII. Craspedote Medusen, Teil I, Lief. 4, pp. 365-479.

Kramp, P. L. 1926. Occasional Notes on Coelenterata. I. Vidensk. Medd. fra. Dansk naturh. Foren., Bd. 82, pp. 241-247. 